\title{
A poesia da música ou a música da poesia: a estruturação poética da fraseologia em alguns exemplos de música popular do Brasil
}

The poetic Structuring of music phraseology from some examples of Brazilian Popular Music

Paulo Tiné 


\section{Resumo}

Este artigo trata de uma proposta no campo da teoria musical através de analogia entre a construção fraseológica musical e a elaboração poética. A metodologia parte dos tópicos de tratados históricos sobre a fraseologia musical e temas filosóficos ligados à poética. Como resultado, através de uma prática analítica e do confronto da fraseologia com regras de poéti$\mathrm{ca}$, chega-se a uma proposta de duas novas categorias fraseológicas. Concluindo, as estruturas fraseológicas de músicas do repertório popular brasileiro poderiam ser entendidas como análogas a certas estruturas poéticas, ensejando-se, desse modo, discussões conceituais derivadas da problemática apresentada.

Palavras-chave: Fraseologia; estruturação musical; estruturação poética; música popular.

\section{Abstract}

This article deals with a proposal in the field of music theory through analogy between phraseology of music and poetic elaboration. The methodology starts from the themes of the historical treatises on music phraseology and philosophical themes on poetry. As a result, through an analytical practice and coping with phraseology with poetic rules, one came to a proposal of two new phraseology categories. Concluding, the phraseology of music structures of the songs in the Brazilian popular music repertoire could be understood as analogous to certain poetic structures, thus, leading to conceptual discussions derived from the problem presented.

Keywords: Phraseology of music; musical structure; poetic structure; Brazilian popular music.

Paulo Tiné é Professor Doutor do Departamento de Música do Instituto de Artes da Universidade Estadual de Campinas (UNICAMP) desde 2012 na área de Música Popular com especialização em Harmonia e Arranjo. Doutorou-se em 2009 pela ECA-USP pesquisando o modalismo na música brasileira. Em 2011 lançou o livro "Harmonia: Fundamentos de Arranjo e Improvisação" pela editora Rondó e apoio FAPESP, hoje (2020) na 3a edição. Em 2016 publicou o álbum de partituras para violão "10 Peças para Violão: Solo Brasileiro, Anos 90" pela editora Rondó e apoio FAEPEX para CD anexo. Como músico (violonista, compositor, arranjador e diretor) lançou 5 trabalhos, o último "Paulo Tiné \& Ensemble Brasileiro" lançado em 2017/18. É líder do grupo de pesquisa "Transcriações Musicais" e representa o curso de música popular da UNICAMP na REMPUL (Rede para o Estudo de Música Popular em Universidades Latino-americanas). 


\section{Introdução}

Na obra Fundamentos da composição musical, de Arnold Schoenberg (1991, p.51), o compositor austríaco faz um interessante paralelo entre música e linguagem. Como muitos outros autores de diferentes maneiras ${ }^{2}$, o autor coloca qual seria para ele o verdadeiro objetivo da música: "O real propósito da construção musical não é a beleza, mas a inteligibilidade". Para justificar tal ponto de vista, o autor dá ênfase à repetição, ou seja, confere à repetição o status de fator gerador da inteligibilidade, ainda que, do ponto de vista composicional, Schoenberg pareça buscar exatamente o oposto no período do atonalismo livre. Em O Caminho para a Nova Música, Anton Webern (1984) retira o motivo de um trecho gregoriano para construir sua leitura da história a partir do material musical; entretanto, ignora que o texto dá suporte à estrutura da melodia do cantochão apresentado.

Há pouco, disse que o princípio primeiro é a apreensibilidade [sic]. Como ele se expressa aqui? É admirável a maneira pela qual todos os princípios já aparecem nessa peça! O que nos chama a atenção inicialmente? A repetição! Isso nos parece quase infantil. Como posso assegurar mais facilmente a apreensibilidade? Através da repetição. É ela que está na base de toda construção; todas as formas musicais repousam sobre esse princípio. (WEBERN, 1984, p.53-54).

Por consequência, tal repetição de motivos, semifrases, frases, antecedentes e de seções inteiras - chamados respectivamente por incisos, membros de frase, frase do período etc., na linhagem de Júlio Bas (2010) - é, na visão desses autores, fatores geradores de inteligibilidade, ainda que, segundo Schoenberg, a repetição excessiva também possa correr o risco da monotonia. No trecho do texto intitulado "Leis da Compreensibilidade", publicado por Dunsby e Whittall (2011), Schoenberg se reporta aos motivos em sua sétima lei:

A apresentação de ideias se baseia nas leis da coerência musical. Como consequência destas, tudo em uma obra musical deve ser explicável como sendo desenvolvido a partir de um motivo básico ou no mínimo de uma forma básica. (SCHOENBERG apud DUNSBY; WHITTALL, 2011, p.68).

Nesse contexto, abundam analogias da linguagem musical com a verbal e, portanto, com a linguística. A própria teoria musical toma de empréstimo conceitos gramaticais ligados à teoria da comunicação. Conceitos como "frase", "linguagem composicional" e "idiomático" são alguns exemplos disso. Essa relação entre música e linguagem pode trazer contribuições importantes ao campo da cognição musical.

2 "Acredito que a composição não se ensina. Entretanto, o que sempre trabalhei em classe foi o entendimento da música enquanto linguagem. É necessário aprender a falar. E para isso é fundamental que se pratique essa linguagem. Em minhas aulas partia da base pessoal de cada aluno, que chamo de 'acontecimento acústico', e procurava transformá-lo em um 'acontecimento linguístico'. Sem isso não é possível compor" (OLIVEIRA, 2006, grifo meu). 
Seria de se esperar, portanto, que qualquer introdução do estudo da música nas disciplinas cognitivas envolvesse de alguma forma uma relação com a linguagem; de fato [...] a relação entre música e linguagem parece sempre necessária e natural, dentro da literatura sobre cognição musical. (MELLO, 2003, p.89).

Entretanto, o que se pretende aqui é realizar um paralelo entre as estruturas fraseológicas e as estruturas poéticas básicas, a fim de verificar sua correlação e tomar a repetição não como um princípio gerador de inteligibilidade, mas como elemento análogo à rima poética.

\section{Justificativa e primeiros exemplos (a poesia da música...)}

Para os resultados aqui apresentados, trabalhei com a hipótese de haver uma analogia de elementos da arte poética como estruturantes da fraseologia musical dentro de um repertório selecionado. Não que a poesia esteja necessariamente presente como texto, o que também pode ser o caso, mas que a organização dos materiais se dá, pelo menos numa primeira instância, de maneira poética. Por isso, aqui, o motivo musical (ou inciso) e suas repetições poderiam ser vistos (e ouvidos) como análogos às rimas, aliterações ou assonâncias ${ }^{3}$, e não como um elemento gerador da inteligibilidade. Mesmo assim, as repetições de frase poderiam ser vistas com esse objetivo, ou seja, o de se rimar musicalmente.

Entretanto, antes dessa analogia e dentro de uma perspectiva teórica, trabalhei normalmente com as seguintes categorias fraseológicas: estruturas binárias classificadas como período ou sentença ${ }^{4}$ (regulares ou irregulares) e estruturas ternárias ${ }^{5}$ (regulares e irregulares). Dentro dessas categorias, podem se desenvolver subgêneros, como o da "cadeia de frases", no caso da sentença (a a'a" etc.), e o da barform", como uma das possibilidades de estrutura ternária. Mais recentemente, a perspectiva de William Caplin (2013) atualiza tais conceitos e terminologias da fraseologia musical, trazendo à tona a discussão de que esse campo teria sido menos desenvolvido principalmente

$3 \quad$ Ver Goldstein (2005, Cap. 7 e 8).

4 "A estrutura do início determina a construção da continuação [...]. Se o início é uma frase de dois compassos, a continuação (C. 3 e 4) pode ser tanto uma repetição exata quanto uma repetição transposta [...]. A estruturação do início determina a construção da continuação. O período difere da sentença pelo fato de adiar a repetição. A primeira frase não é repetida imediatamente, mas unida a formas-motivo mais remota (contrastantes), perfazendo, assim, a primeira metade do período: o antecedente. Após esse elemento de contraste, a repetição não pode ser muito adiada, a fim de não colocar em perigo a compreensibilidade" (SCHOENBERG, 1991, p.48).

5 "Tanto a frase como cada um de seus grupos componentes são binários quando constam de duas divisões principais - sejam períodos ou grupos de períodos - e ternários quando constam de três. A estrutura de um grupo não prejudica a nenhuma dos demais" (ZAMACOIS, 1985, p.19). Grifos do autor. Todas as traduções próprias.

6 “Ordinariamente a repetição de uma parte não tem significado na análise formal. Se nós fazemos uma exceção aqui é apenas porque a barform tem sido reconhecida por séculos como uma entidade específica. De fato, ela tem uma história maior do que qualquer outra forma simples. Ela apareceu durante a Idade Média na música da igreja oriental, tendo sido prenunciada nas Odes da antiga Grécia. Posteriormente ela se tornou a base do canzo dos trovadores de Provence e a partir dali foi para norte da França e estruturou a ballade dos trovadores. Os minnesingers, e depois deles os meistersingers, cultivaram essa forma acima das outras e foi a partir deles que o nome 'barform' derivou. Na nomenclatura medieval alemã, a primeira parte e suas repetições eram chamadas de stolen (estrofes), e a segunda parte de abgesang (após a canção). Esses termos são usados em inglês e alemão, mas escritores preferiram adotar os nomes das partes das antigas odes gregas: parte um chamada de estrofe, sua repetição de antístrofe e a parte dois de epodo. Após o declínio dos meistersingers, a forma continuou a aparecer nos corais protestantes e nas canções folclóricas" (GREEN, 1964, p.80). 
pela influência das teorias de $\mathrm{H}$. Schenker no século $\mathrm{XX}$, enfatizando as reduções a partir de abordagens contrapontísticas e distinções entre as gramaticalidades harmônicas, valorização das linhas fundamentais, e passando ao largo das divisões fraseológicas e estruturais propostas pelos antigos tratadistas das formas musicais.

Um fator importante na decisão desses componentes fraseológicos é, no caso da música tonal, a presença das pontuações harmônicas, implícitas às melodias ou provocadas por sentenças ou sequências harmônicas.

As cadências harmônicas pontuam o discurso musical, indicando o término das frases e dos períodos, também o tema é normalmente delimitado por uma cadência. Essa pontuação pode gerar o término real do discurso ou criar a expectativa de uma continuação. A cadência perfeita ou fina indica um término (de toda a peça ou de seção); a cadência imperfeita, semicadência ou cadência à dominante pontua, mas denota uma continuação. A cadência interrompida ou de engano (ou ainda a cadência evitada), a despeito da sua utilização como ornamento e embelezamento (graças ao efeito surpreendente que pode gerar), tem uma finalidade claramente perceptível: anuncia uma cadência perfeita que não se cumpre, abrindo espaço para novas digressões; nisso reside sua mais destacada função estrutural. (ASSUMPÇÃO, 2007, p.34-35).

O trabalho citado de Sérgio Assumpção propõe, então, uma associação entre as figuras da fraseologia musical com a arte da retórica. Nesse caso, por exemplo, a divisão proposta por Schoenberg entre período e sentença pode ser análoga aos estilos periódicos e lacônicos dessa arte.

No estilo periódico, as frases são compostas de muitos membros ligados entre si e dependentes uns dos outros, de maneira que o sentido só no fim é completamente conhecido. É a maneira que convém melhor à arte da oratória, porque mantém em "suspense" o ouvinte. [...] O (sic.) estilo lacônico temos nas frases curtas completas, independentes uma das outras, que encerram um sentido integral. [...] Quando o assunto é leve, esse estilo é mais apropriado. Mas, com hábil combinação (naturalmente obedecendo o assunto), o orador pode obter efeitos extraordinários. Quando se deseja descrever uma ação rápida, as frases curtas são mais impressionantes. Quando se trata de descrever uma ação mais tranquila, um período mais longo causa maior efeito. (SANTOS, 1954, p.33-34. Grifos do autor).

Está claro que tais conceitos não se aplicam diretamente ao conteúdo musical, mas, dentro dessa perspectiva, é como se a retórica o estruturasse ${ }^{7}$. Voltando a Júlio Bas, o autor utiliza outra denominação para o termo frase: é comum encontrar a denominação de "semiperíodo" em trabalhos que tiveram como base seu tratado publicado pela primeira vez em 1913. Assim, a combinação dos "semiperíodos" comporia o período que, nesse caso, forma o antecedente. Os conceitos de antecedente e consequente, por sua vez, já foram objetos de tratados filosóficos e de ciências culturais.

\footnotetext{
7 O campo de relação entre música e retórica é extremamente antigo e amplo e remete a autores como Gioseffo Zarlino (1517-1590) e à música poética do Barroco alemão de cunho luterano, cuja origem remonta à clássica divisão entre as ciências do Trivium (Retórica, Gramática e Oratória) e do Quadrivium (Música, Geometria, Astronomia e Matemática) propostas pelo filósofo eclesiástico Severino Boécio (480-524 ou 525). Entretanto, a proposta de Assumpção se refere exatamente às formas musicais que assumem maturidade no período clássico, exatamente aquelas que Caplin tomou como repertório modelo para sua obra.
} 
O conceito de antecedente, ontologicamente considerado, é o que procede a outro em qualquer ordem, lenha, vetor, série etc. Ele exige o de consequente. Contudo, se o consequente exige necessariamente o antecedente, este não exige aquele, senão quando recebe essa qualificação. Assim, uma atualização pode, em certa ordem, ser a última sem consequentes. $O$ indivíduo, tomado singularmente, é a última determinação da forma e, em sentido formal, não tem consequente. (SANTOS, 1964, p.111).

Um exemplo da aplicação dessa perspectiva teórica dentro de um corpus musical popular brasileiro, primeiramente do conceito de sentença e, mais especificamente, dentro do repertório instrumental, encontra-se na figura abaixo.
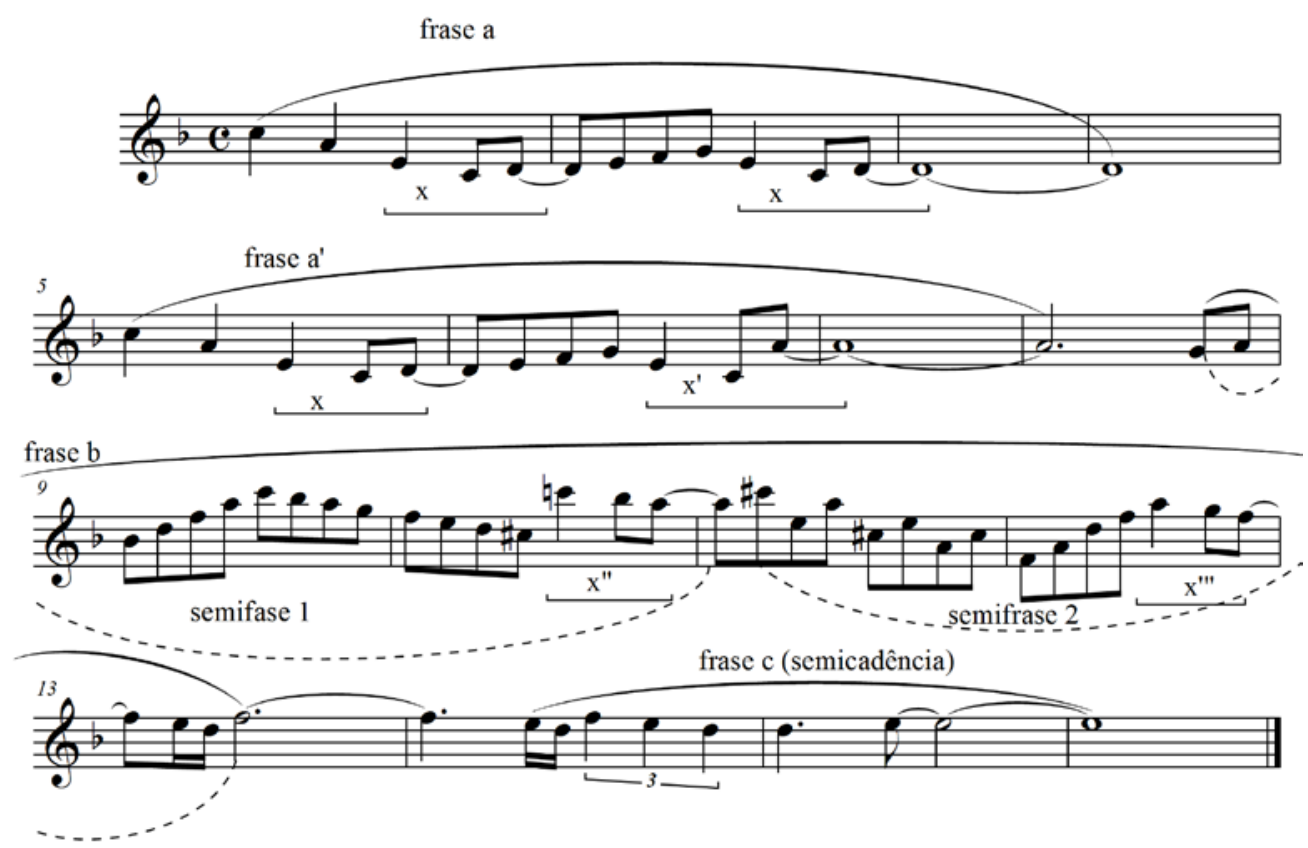

Fig. 1: "Frevo", de Egberto Gismonti: seção A

Trata-se da seção A da peça instrumental "Frevo", de Egberto Gismonti. Foi aqui classificada como uma sentença regular, pois a primeira frase a é repetida logo em seguida com uma ligeira variação no motivo $x\left(x^{\prime}\right)$. Tem na frase $b$ o contraste, uma frase longa de 5 compassos que pode ser segmentada em duas semifrases (1 e 2) e frase semicadencial c de 3 compassos, portanto, terminando de forma interrogativa, indicando a função harmônica de dominante (Absus7(9-)) $)^{8}$. Regular porque toda a sentença ocupa dezesseis compassos. Observa-se a presença do motivo $x$ como elemento unificador presente em quase todas as frases. Entretanto, não se deve ver aí uma intencionalidade de unidade motívica construída à maneira das sentenças de Beethoven (como a do Op. 2, n. 2 - I apresentada por Schoenberg), mas algo fruto da decantação de tais procedimentos passivamente assimilados pelo autor por meio de sua vivência e prática com a 
música ocidental. Já a próxima figura ilustra uma aplicação do conceito do período ao mesmo corpus e recorte mencionado:

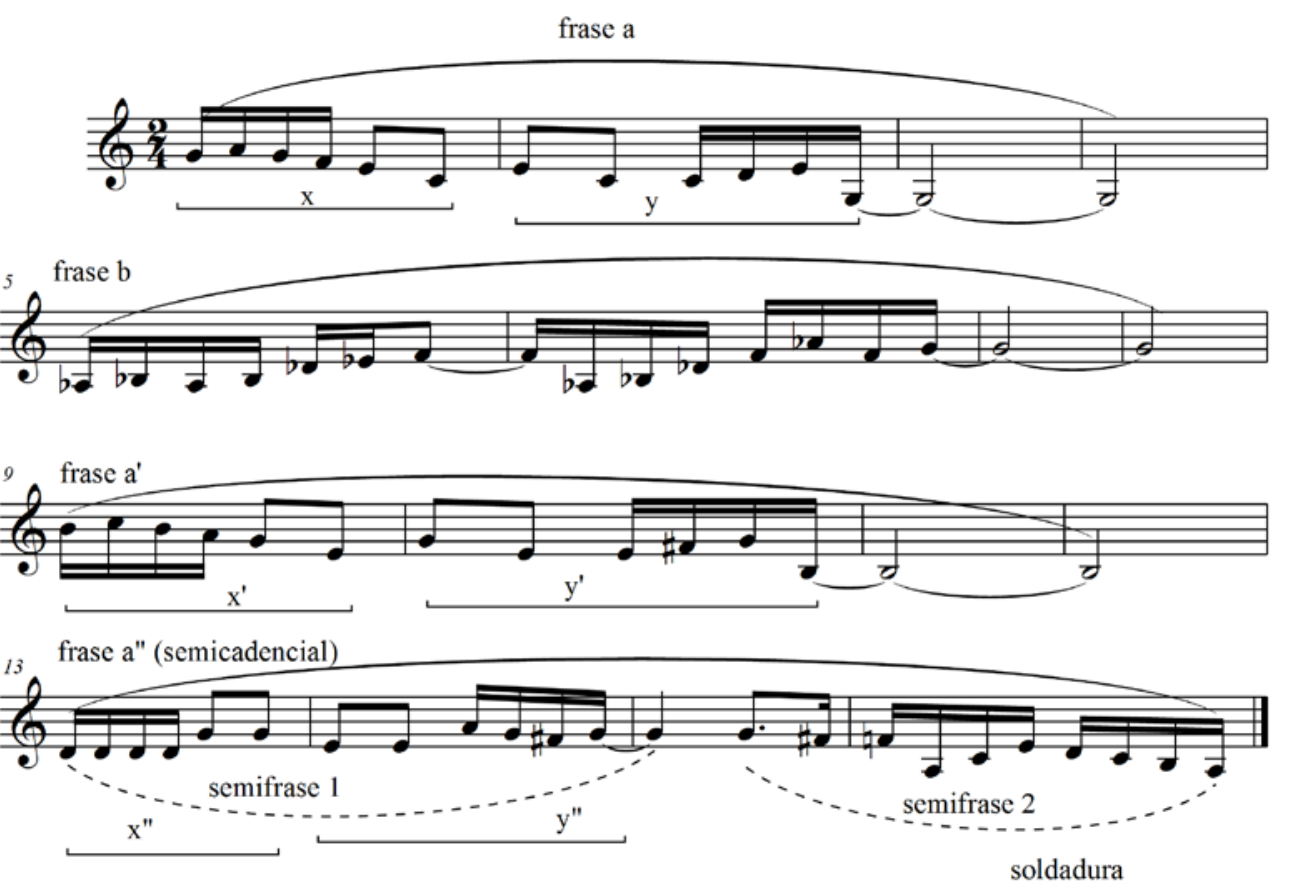

Fig. 2: "Estamos al", de Maurício Einhorn: $1^{\circ}$ período

Trata-se de "Estamos Ai", de Maurício Einhorn. Observa-se que a terceira frase repete a primeira 3 a acima adaptada ao contorno (arpejo com notas de passagem e bordadura) do acorde de Mi menor, já que a primeira estabelece o contorno de Dó maior. Tal transposição se dá pelo encaixe melódico na harmonia do contorno de Dó maior para Mi menor. A segunda frase (b) apresenta um contraste pelo uso de motivos diferentes da frase a. Novamente se observa como elementos unificadores os motivos $x$ e $y$ (evidentemente espelhados um do outro), que passam por diferentes derivações até realizarem a semifrase 1 , semicadencial, pois termina na nota da dominante. A 2 a semifrase é denominada de soldadura por teóricos como J. Zamacois, exatamente por essa função de ligação entre o final de um período e o começo de outro ou sua repetição.

Em relação à estrutura ternária, há referências a ela em J. Zamacois (1985) e Júlio Bas (2010), possivelmente com ascendência do segundo autor sobre o primeiro devido à antecedência histórica do tratadista italiano. Em sua definição, uma estrutura ternária pode se dar em diversos níveis, como o das frases, dos antecedentes e consequentes. Por exemplo, uma estrutura de três frases musicais pode ter seis ou doze compassos, dependendo do tamanho de dois ou quatro compassos por frase. Então, pode-se derivar as seguintes possibilidades: $a, a^{\prime}$ e $a^{\prime \prime}$ (cadencial); $a$, a' e $b$ (cadencial); $a, b$ e b' (cadencial) e, por fim, $a, b$ e $c$ (cadencial). A primeira possibilidade é a da cadeia de frases em estrutura ternária (também presente em estruturas binárias), e, por fim, a segunda derivação é a da chamada barform (ver nota de rodapé no 5), estrutura poética que remonta à Idade Média e à Grécia antiga empregada, por exemplo, na ópera de Richard Wagner, Os Mestres Cantores. 
Um exemplo bastante conhecido de estrutura ternária na música popular afro-americana é a do blues, principalmente naquela fórmula de 12 compassos (estrutura ternária), que o jazz adotou a partir da década de 1920 em relação a esse gênero. Observamos diversos temas de jazz organizados em estrutura ternária e, inclusive, dentro da barform, como "Blue Monk" (T. Monk), "Nostalgia in Time Square" (C. Mingus), entre outros $^{9}$. Outra possibilidade de estrutura ternária se dá quando há dois antecedentes e um consequente ou um antecedente e dois consequentes em uma seção musical. Observa-se nesses casos uma totalidade de 24 compassos, como no caso a seguir.
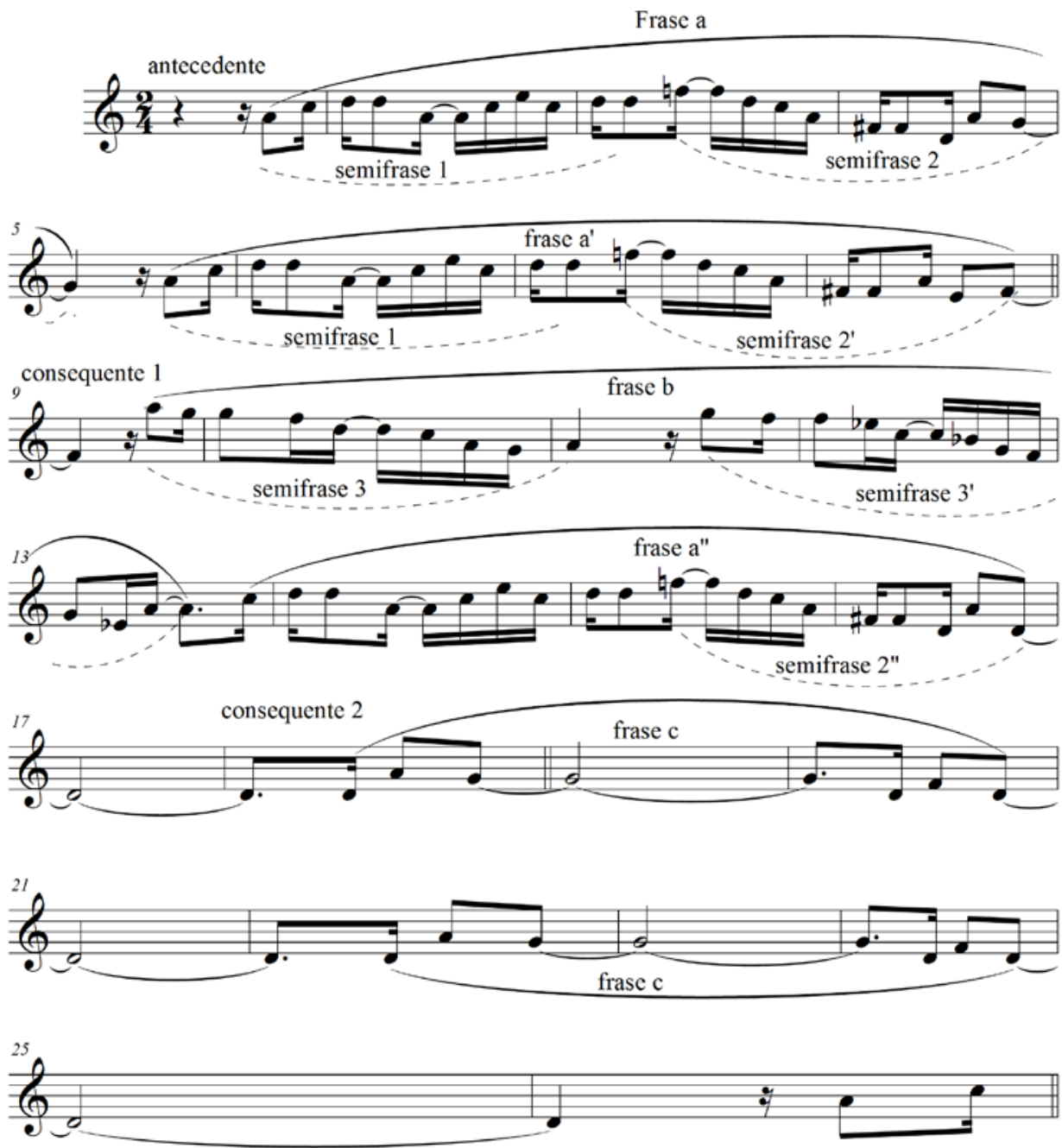

Fig. 3: "Nanã", de Moacir Santos

Trata-se, nesse caso, de um antecedente com dois consequentes. Retirando o primeiro compasso, sendo uma anacruse, a estrutura totaliza 25 compassos, tornando-se, então, uma estrutura ternária irregular. Tal irregularidade se dá exatamente no 17으 compasso, pois, ali, o arranjo da gravação de referência ${ }^{10}$ realiza uma frase de resposta. Entretanto, a classificação de "Nanã" como estrutura ternária se dá a partir da partitura

9 Lacerda (2001) lançou apontamentos sobre a estruturação da barform na música nagô-ioruba.

10 Santos (1965, faixa 3). 
de referência ${ }^{11}$, pois, em duas importantes gravações arranjadas pelo compositor (nos álbuns Coisas e Você Ainda Não Ouviu Nada ${ }^{12}$ ), o segundo consequente é executado como coda, fazendo com que a soma do antecedente com o consequente 1 componha uma sentença regular de 16 compassos, devido à repetição imediata da frase $a^{13}$.

Tomando como base essas práticas analíticas e pedagógicas na área da música popular brevemente expostas nos exemplos anteriores, observa-se que diversos exemplos puderam ser classificados, do ponto de vista da fraseologia, dentro daqueles modelos preexistentes apresentados, ainda que cada exemplo possua características próprias e únicas. W. Caplin se propõe a flexibilizar a relação entre a categoria fraseológica e o "encaixe do exemplo" a partir do conceito de ideia. Assim, tomando-se tais possibilidades (estruturas binárias, ternárias) como ponto de partida, a maioria das canções e músicas analisadas em Tiné (2001) se assentou em alguns padrões formais preexistentes, como o da Canção de Uma só Parte (A), Formas Binárias (AB), derivadas (por exemplo: $A A^{\prime}$ ) e Ternárias $(A B A)^{14}$, sendo o $B$ visto ora como outra estrutura em tonalidade diferente, ora como uma Seção Central Contrastante, e, por fim, a forma do choro (ABACA) encontrada, ainda que originária da polca, em diversos exemplos musicais brasileiros. Além disso, para tais possibilidades formais, foi de grande importância verificar a forma da gravação ou do arranjo, pois é nele que a obra musical de cunho popular/comercial se dá do ponto de vista fenomenológico.

As formas mais simples se dão, portanto, quando uma peça inteira está assentada como estrutura binária, ternária regular ou irregular. Stein ${ }^{15}(1979$, p.57) usou o termo forma canção para esse fenômeno dividindo-a em subcategorias. A mais simples delas seria a canção de uma só parte. A próxima figura ("Imagem", de Luiz Eça) é um exemplo curioso dessa possibilidade formal: totalizando 25 compassos, tal fato apontaria, como no caso de "Nanã", ${ }^{16}$ para uma estrutura ternária irregular. Entretanto, constata-se que se trata de quatro frases a com ligeiras modificações entre elas. Além disso, observa-se que as três primeiras frases são constituídas por sete compassos e, na última frase, há elisão entre o fim da frase $a$ " e o início da frase $a^{\prime \prime \prime}$, o que a torna uma frase de cinco compassos. Conclui-se que Imagem é uma canção de uma só parte estruturada em sentença na forma de frases encadeadas. Há ainda outro dado pouco usual nesse tema: Imagem tem como tonalidade de partida Ré maior, mas a frase cadencial se direciona para Sol menor (região da subdominante). Por fim, a conclusão se dá no vamp modal dórico Im7/IV7 (Gm7 / C7).

\section{CHEDIAK, A. Songbook da Bossa Nova, Vol 4. Rio de Janeiro: Lumiar, 1994.}

12 Mendes (1964, faixa 6).

13 Embora "Nanã" não pareça um bom exemplo de estrutura ternária, como a própria versão de Sérgio Mendes sugere, podendo ser apresentado como uma estrutura binária seguida de coda (i.e., função formal - de moldura - localizada após o fim da estrutura formal. Ver Caplin [2013]), tais considerações analíticas serviram de base para a realização do arranjo autoral para big band de "Nanã", cujo tema foi inserido em uma fórmula harmônica do blues. Ver Tiné (2019).

14 Stein (1979, p.57-74).

15 Compositor e professor norte-americano (1910-2002). Sua terminologia se aproxima mais da abordagem schoenbergniana, com a inclusão do conceito de semifrase.

16 Nesse sentido, Nanã e muitos temas de blues já são uma forma canção de uma só parte assentada na estrutura ternária. 

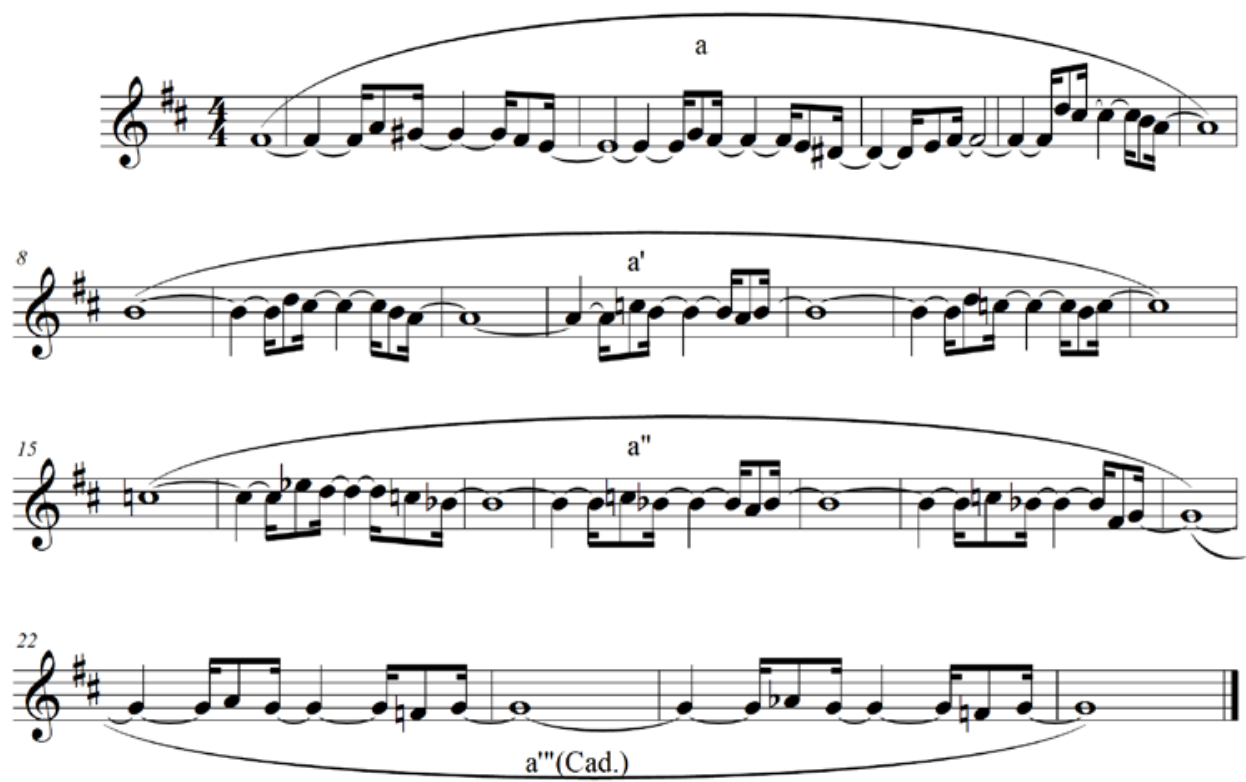

Fig. 4: "Imagem", de Luiz Eça

Uma série de outros temas pode ser apontada dentro dessa possibilidade formal, como "Insensatez" (Jobim e Vinicius), "Autumn Leaves" (J. Kosma) - esses ainda ligados à cadeia de frases -, "Manhã de Carnaval" (L. Bonfá), uma sentença regular, entre muitos outros. Tais estruturas propiciam, por vezes, harmonias modulantes como a música em questão, ou seja, sua simplicidade motívica e fraseológica é compensada por uma complexidade harmônica. É possível conferir isso por meio da análise harmônica abaixo.

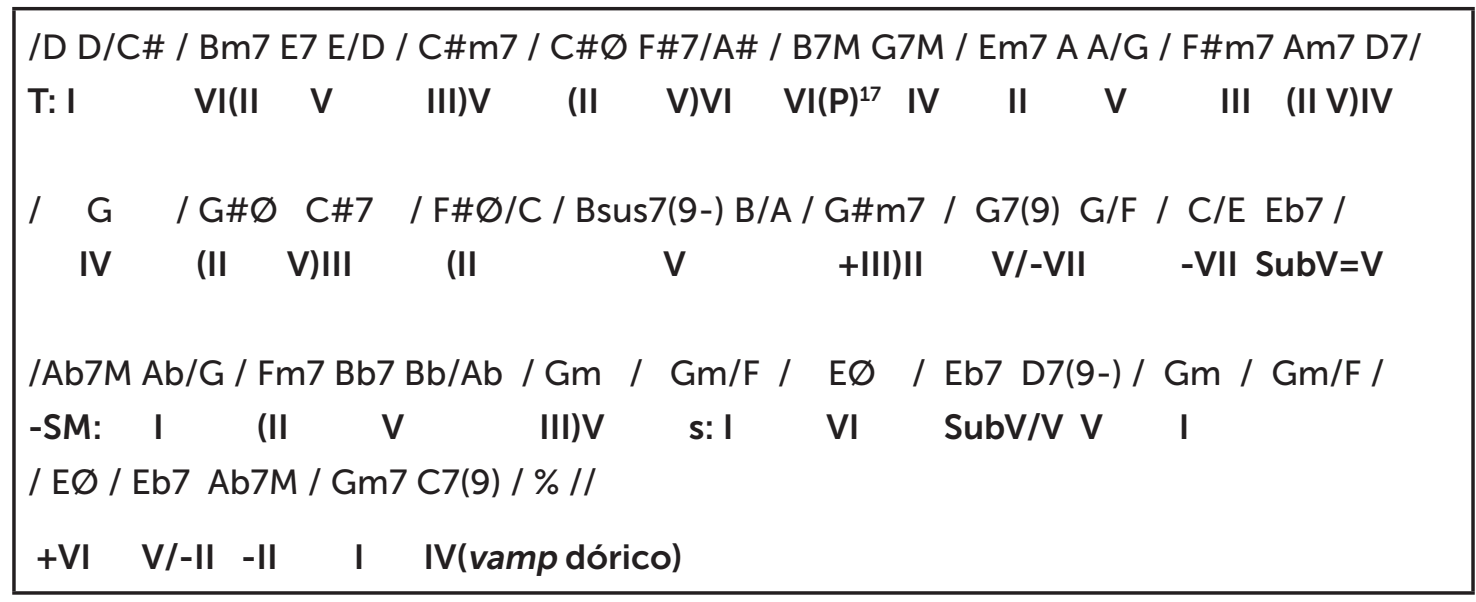

Quadro 1: Harmonia de "Imagem"18

17 Acorde de $3^{\mathrm{a}}$ (e $7^{\mathrm{a}}$ ) de picardia no VI grau. As indicações de T, -SM e s correspondem à tônica maior, submediante maior rebaixada e subdominante menor respectivamente, ou seja, as tonalidades de Ré maior, Lab maior e Sol menor.

18 Utilizou-se, basicamente, a padronização de cifras adotadas por Almir Chediak, exceto para os acordes meio-diminutos. 
Como colocado, a escolha dos exemplos se deu, por um lado, pela pesquisa realizada e, por outro, pela prática pedagógica da análise musical aplicada. Foi dentro dessa perspectiva que as categorias fraseológicas supracitadas foram aplicadas em exemplos daquele vasto repertório de música popular brasileira. Nesse contexto, tratava-se, também, de se analisar diversas atividades musicais significativas relacionadas a gêneros ligados à música popular, principalmente instrumental, como o frevo e o choro, análise de improvisações, arranjos em geral, de canções e standards de jazz.

Após as formas binárias, que serão comentadas no próximo item do artigo, uma das formas ternárias mais utilizadas pelo jazz foi o chamado Rhythm Changes, que se baseou na estrutura harmônico-formal da canção de George Gershwin, "I Got Rhythm", composta em 1930 para o musical Girl Crazy. Tal estrutura, afora a simplicidade e talvez até por isso, se tornou paradigmática: além de gerar o "changes"19 mencionado, foi a base da obra para piano e orquestra de "Variações sobre I Got Rhythm", do próprio Gershwin, em 1934. Entretanto, quando se ouve a gravação das improvisações sobre o tema pelo grupo do clarinetista Benny Goodman em 1939 no famoso concerto no Carnegie Hall, observa-se que, na repetição do último $A$, da estrutura AABA, há 10 compassos, em vez dos 8 compassos das seções $A$ anteriores, fazendo com que esse AABA se transformasse em AABA'. Entretanto, na apropriação da estrutura que se fez a partir da era do BeBop, esse último $A$ foi adaptado aos oito compassos deixando a quadratura do chorus regular e mais própria para a improvisação, semelhante a temas como "Antropology", "Red Cross", "Moose The Mooche", "Chasin The Bird", entre tantos outros de Charlie Parker e outros autores. O quadro abaixo apresenta a estrutura básica do Rhythm Changes e uma de suas famosas variações.

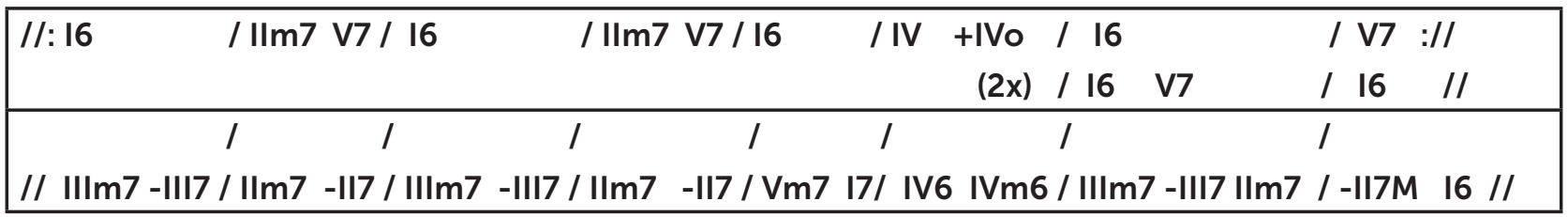

Quadro 2: Rhythm Changes, seção A, modelo e variação

Observa-se que o I grau foi substituído pelo III, acordes afins segundo a harmonia funcional (tônica paralela), ou seja, de mesma função. Antes do II grau que realiza a cadência II-V, ocorre o III grau dominante rebaixado meio tom, o que significa que ele exerce função de "subV do II", ou seja, de substituto da dominante do II grau. Também ○ V grau do $2^{\circ}$ compasso é substituído pelo subV. Essa cadência (IIIm7 - III7 IIm7 -II7), ${ }^{20}$ ou turnaround, se repete perfazendo, assim, a estrutura da sentença ao nível harmôni$\mathrm{co}^{21}$. Em seguida há a substituição do I grau pela cadência secundária II - V do IV que

\footnotetext{
19 entendimento comum do meio jazzista sobre os chamados changes é o de que se trata de estruturas fixas ou fórmulas harmônicas, sendo as mais conhecidas as do blues (maior e menor), rhythm changes e o Coltrane changes.

20 Nesse ponto, não se trata de uma análise das funções harmônicas, mas de uma descrição do movimento dos acordes através dos graus da escala para efeito do entendimento de uma estrutura que se pode transpor para qualquer tonalidade, nos moldes das fórmulas (changes) mencionadas.

21 Na obra "Funções estruturais da harmonia", de Schoenberg (2004), especificamente no capítulo "Progressões para diversos propósitos composicionais", há a aplicação dessas possibilidades fraseológicas na harmonia.
} 
ocorre na transformação em Vm7 e 17 (se colocássemos a estrutura em Dó maior, os acordes seriam Gm7 C7). No lugar do IV grau diminuto alterado ascendentemente no 6을 compasso, há o uso do acorde de subdominante menor para a repetição modificada da cadência original nos últimos compassos com a utilização da versão plagal da cadência napolitana (-II/I) no último compasso.

Trata-se, evidentemente, de uma "brincadeira analítica"22 com as derivações do "changes" mencionadas que, através dessas variações harmônicas, gerariam a estrutura da seção A de "Samba de uma nota só" (Tom Jobim e Newton Mendonça). Não acredito ter havido uma atitude intencional em relação a essa apropriação, mas a prática da execução dessas músicas pode ter feito Jobim ter se apropriado e derivado a canção da estrutura. Na seção B, algo completamente diferente ocorre:

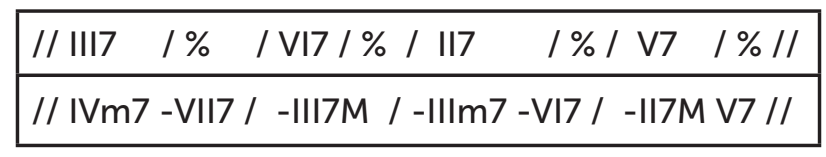

Quadro 3: Rhythm Changes: seção B, modelo e variação

Observa-se que em B Jobim já se afasta bastante do original. De um ciclo de acordes dominantes que partem do III grau característicos dessa seção do Rhythm Changes, Jobim realiza duas cadências auxiliares em direção ao III e II graus rebaixados. Além disso, transforma uma estrutura de oito em quatro compassos, com apenas duas frases. Por fim, na repetição da última seção $A$, há uma pequena alteração da harmonia nos acordes finais da canção de Jobim: a subdominante menor do segundo tempo do 60 compasso é substituída pelo -VII7, ou seja, dominante do -III, para na cadência final perfazer // -III6 / IIm7 / -II7M / I6 // nos versos "fica sempre sem nenhuma, fique numa nota só"23.

Esse tipo de seção B realizado por Jobim, com metade do número de compassos da seção A, corresponderia àquilo que, na forma ternária, Schoenberg denominou por "seção central contrastante". Caracteriza-se, via de regra, por uma estrutura fraseológica que não está em tonalidade distinta da tonalidade da seção A, porém costuma explorar regiões tonais distintas (no caso, as cadências auxiliares); em outras palavras, não modula, mas é modulante, não se fixa em outra tonalidade, mas permanece em fluxo.

Riemann (1950, p.153-159) denomina a seção B como "segundo tema", aludindo ao fato de essa seção poder trazer materiais temáticos distintos. Assim, divide em quatro os tipos de ordenação ABA, chamando por "Ideia principal - Ideia secundária - Ideia principal", e classificando entre aqueles que possuem um ou mais temas e aqueles que possuem desenvolvimento temático. O modelo que possui a seção central contrastante 
corresponde ao que chamou de "primeira forma". Há também a possibilidade de a seção B se constituir como período ou sentença, o que corresponde à segunda forma proposta por Riemann (1950, p.157), com o membro intermediário. Em alguns casos, mesmo em se tratando de estruturas binárias, e não de seções centrais contrastantes, uma característica dessa última se mantém, a saber, a propriedade de não modular, mas de ser modulante, fato caracterizado como "período intermediário de desenvolvimento autônomo".

Como mencionado, o corpus referencial no qual os autores Riemann e Schoenberg construíram suas teorias foi o dos compositores europeus ocidentais, principalmente aqueles dos períodos clássico e romântico. Nesse sentido, mais uma vez, há a valorização do desenvolvimento da forma por meio de uma leitura teleológica em direção à forma sonata e na legitimação desses assim chamados "grandes maestros". Portanto a terceira e quarta formas de Riemann apontam para o procedimento do desenvolvimento, raramente encontrado em compositores do corpus aqui utilizado, no sentido de fundamentar sua teoria da forma. Entretanto, alguns procedimentos são coincidentes, seja pela natureza intrínseca do material tonal, seja por uma assimilação passiva dos procedimentos dos autores ocidentais pelos compositores populares brasileiros ou jazzísticos. Assim, constata-se, por exemplo, que a seção B de "Prelude to a Kiss", de Duke Ellington, um período em tonalidade contrastante, é completamente diversa da seção B de "Desafinado", por exemplo, por esta não estabelecer uma tonalidade, mas realizar diversas digressões harmônicas.

O caso emblemático de Ernesto Nazareth é bastante significativo para o fenômeno da forma do choro, no entanto algumas considerações podem ser realizadas. É comum encontrar na seção $C$ de diversas partituras de Nazareth, e posteriormente de choro em geral, a expressão "trio". Como se sabe, a origem de tal termo remonta à sinfonia pré- clássica na qual a seção central do minueto era tocada por três instrumentos. A forma "minueto I - minueto II (trio) - minueto I", que já aparece no período barroco, corresponde ao que Reimann denominou com sendo sua terceira forma.

Os tipos mais puros da terceira forma se encontram em danças de origem mais recente (as mais antigas se limitam em geral a uma execução mais ou menos desenvolvida das formas primeira ou segunda, quer dizer, apresentam um só tema ou introduzem entre suas duas exposições uma parte central que contrasta com o mesmo, ao modo do trio); os melhores exemplos da dita terceira forma são encontrados em marchas e sherzi... (RIEMANN, 1950, p.190) ${ }^{24}$.

Abaixo, encontra-se o choro "Segura Ele", de Alfredo Rocha Vianna Filho, o Pixinguinha, compositor que herdou da geração de E. Nazareth, Chiquinha Gonzaga e Anacleto de Medeiros em suas composições a estrutura formal do gênero e a manteve em grande parte de suas obras, constituindo, a partir dessa base, alguns modelos de choro para música popular no Brasil. A seção A está estruturada em período regular (16 compassos) na tonalidade de Dó maior. Na seção B ocorre um interessante fenômeno

$24 \quad$ Não tendo acesso ao original em alemão dessa obra e trabalhando com a tradução para o espanhol, não vi necessidade em inserir o texto da edição utilizada, dada a proximidade entre os idiomas. O mesmo vale para as traduções de Zamacois (1985) e Delgado (2016), embora tais obras tenham sido escritas diretamente em espanhol. 
fraseológico: não há repetições de frase para que se possa caracterizar como período ou sentença, muito embora haja uma regularidade: 16 compassos na região da submediante menor (Lá), divididos em quatro frases, duas para o antecedente e duas para o consequente, sendo a última cadencial. É exatamente a essa falta de encaixe que será sugerida uma possibilidade de leitura nos itens a seguir ${ }^{25}$. Já a última seção classifiquei como sentença regular, muito embora a repetição também não seja explícita entre as frases a e a', mas a semelhança se verifica pela presença, em ambas as frases, da hemíola ou do ritmo cruzado assinalado na partitura.

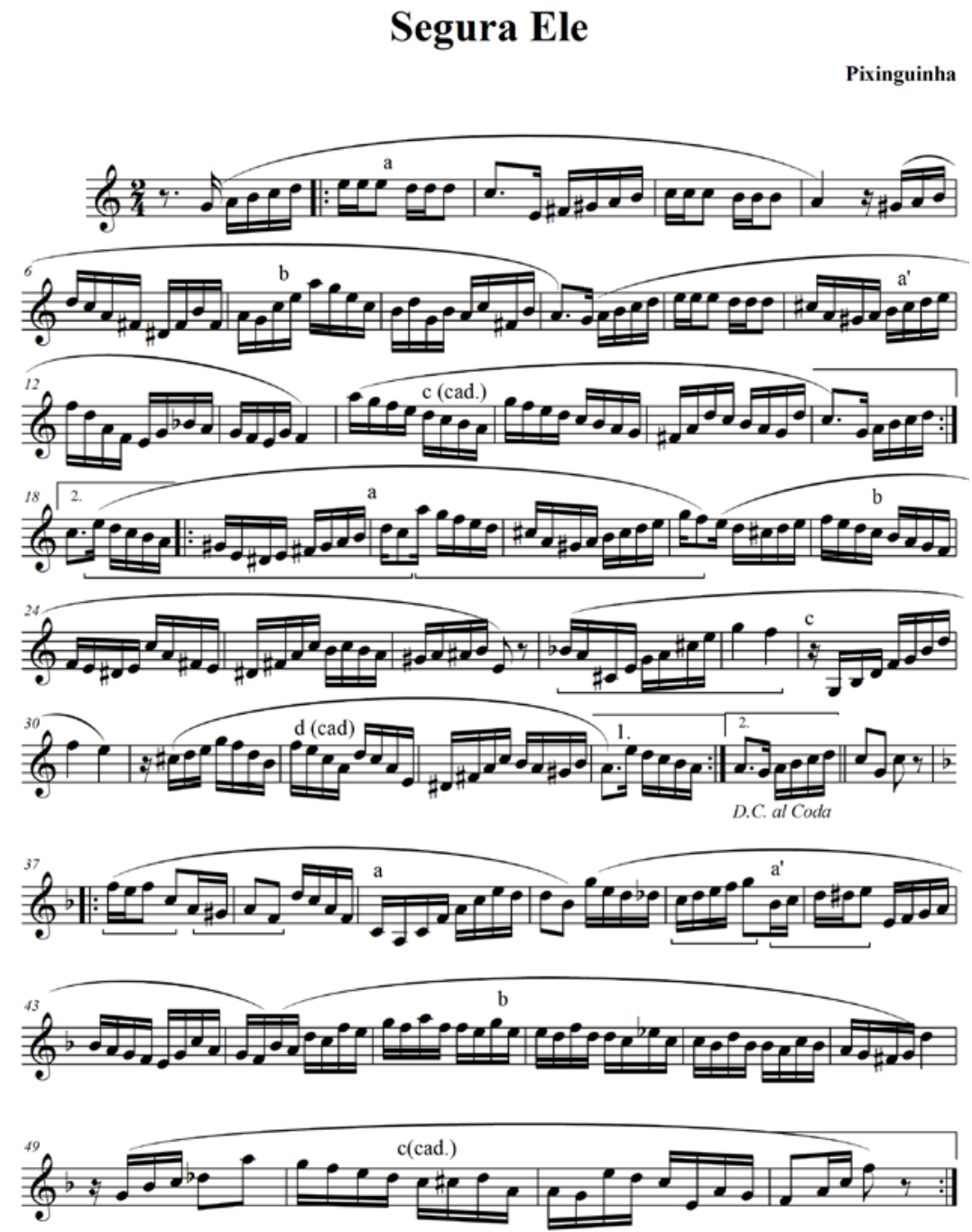

Fig. 6: "Segura Ele", de Pixinguinha

Essa prática analítica, como demonstrada parcialmente acima, serviu como uma espécie de laboratório de pesquisa. Ao mesmo tempo, outros exemplos que serão apresentados foram retirados da minha tese de doutorado (TINÉ, 2008), apontando para uma interessante relação entre alguns protótipos formais em gêneros da música po- 
pular. Nessa, além da prática mencionada, foi incluída uma série de exemplos étnicos de gêneros, como cocos, catimbó, capoeira, candomblé e cantoria, transcritos a fim de se buscar uma antecedência dos procedimentos modais nos compositores populares, analisados no capítulo IV da tese, Edu Lobo (cujo trecho é citado adiante), Baden Powell e Milton Nascimento. Entretanto, a análise dos procedimentos fraseológicos foi realizada em paralelo à do modalismo. Por fim, nessa sobreposição de elementos fraseológicos, estruturas poéticas e modalismo (principalmente aquele encontrado na música nordestina), há um desembocar, quase que natural, em parte dos procedimentos da música de Hermeto Pascoal, na medida em o multi-instrumentista parece atingir um novo fazer musical que, entretanto, não deixa de ter sua base no desdobramento de procedimentos musicais do nordeste brasileiro, principalmente a cantoria. Tal metodologia, como se verá, em vis-à-vis, entre estruturação poética e fraseológica, foi utilizada em artigos e capítulos posteriores à tese mencionada, a fim de trazer elementos para as análises realizadas (TINÉ, 2016, 2017).

\section{Outros exemplos (a música da poesia...)}

Uma breve alusão a essa possibilidade de inter-relação entre poética e fraseologia encontra-se pré-configurada já em Hugo Riemann (1950, p.35) ao comentar o Op. 7 de Beethoven. Em complemento, alguns pesquisadores apontaram o mesmo paralelo, por exemplo, no campo da etnomusicologia, entre a fraseologia musical e a versificação poética; nesse caso, na tradição musical ioruba do Benin. ${ }^{26}$

A abordagem de canções com letra, ou seja, canções com o texto poético presente, pode clarear ainda mais a relação entre métrica e fraseologia, ainda que se pretenda abordar aqui o nível musical puro ou neutro. Em muitos exemplos, a quadra poética ${ }^{27}$ permanece análoga às estruturas binárias do período ou sentença, e as sextilhas e tercetos à estrutura ternária. Há que se ter em conta que, de uma maneira geral, dentro das manifestações étnicas brasileiras, não há uma dissociação desses termos, quer dizer, não há a composição destes em separado; eles são criados às vezes improvisados ou ao mesmo tempo. O caso da cantoria nordestina (RAMALHO, 2000) é significativo, pois para uma mesma melodia são improvisados diferentes versos que, via de regra, obedecem a uma mesma métrica. Apresento, como exemplo disso, um trecho transcrito retirado do CD A Arte da Cantoria: Ciclo do Cangaço, faixa 2. Ele se baseia na Sextilha, ou seja, a estrofe possui seis versos de sete sílabas (GOLDENSTEIN, 2005). Portanto, a estrutura ternária formada pelas frases $a, b$ e $b$ ' é consequência direta do uso da sextilha. O mesmo vale para os padrões conhecidos entre os repentistas como "Oito pés ao Quadrão" e "Dez pés ao Quadrão"28. Os números no exemplo apontam os traços cadenciais em relação ao modo.

\footnotetext{
26 Ver Lacerda (2001).

27 Estrofe poética de quatro versos cada (GOLDENSTEIN, 2005).

28 Estrofes de oito e dez versos de sete sílabas (redondilha maior), respectivamente.
} 


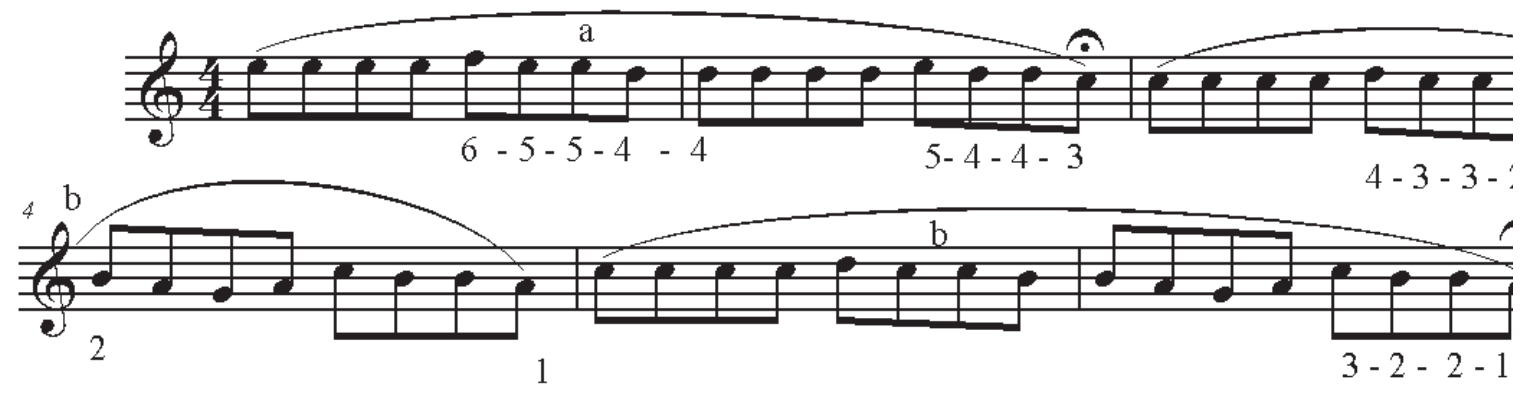

Fig. 7: Exemplo de cantoria

Nota-se, nesses casos, a ascendência do canto silábico sobre o melismático, que se estende dos campos étnicos brasileiros aos populares nos exemplos estudados. $\mathrm{Na}$ verificação da transposição de tais elementos pelos autores populares estudados, como Luiz Gonzaga, Jackson do Pandeiro, Edu Lobo, Milton Nascimento e Baden Powell, percebe-se que, nesses autores e na maioria dos casos, a melodia foi criada primeiro para, posteriormente, ser acrescida a letra. Nesse caso, normalmente, uma irregularidade fraseológica é correspondida por uma irregularidade métrica. É importante ressaltar o papel que o responsório exerce em alguns exemplos, no sentido de adaptar certas inconstâncias métricas de algumas estruturas poéticas em regularidades fraseológicas, procedimento muito presente em manifestações populares em geral. Observe abaixo o quadro com a comparação entre métrica, rima e fraseologia da parte A de "Arrastão" (Edu Lobo e Vinícius de Moraes). Nesse caso, o verso corresponde à frase musical e a melodia, tal qual muitas cantorias nordestinas, acomoda a redondilha maior. Entretanto, a rima não condiciona o contraste fraseológico, mas, sim, a métrica, que, sendo sempre a mesma, termina por se conformar às repetições - frases $a$, $a^{\prime}, a^{\prime \prime}$ e $a^{\prime \prime \prime}$ cadencial -, enquadrando-se, portanto, à estrutura da sentença na forma de cadeia de frases.

Letra
\begin{tabular}{|lcc|lll|}
\hline$\hat{E}$, tem jangada no mar & $(7)$ & $a$ & Frase $a$ & Final \\
\hline$\hat{E}$ (ie, iêi) hoje tem arrastão & $(7)$ & $b$ & Frase $a^{\prime}$ & \\
\hline É, todo mundo pescar & $(7)$ & $a$ & Frase $a^{\prime \prime}$ & \\
\hline Chega de sombra João & $(7)$ & $b$ & Frase $a^{\prime \prime \prime}$ (frase cadencial) & $2-7+1$ \\
\hline
\end{tabular}

Quadro 4: "Arrastão": seção A

A partir das categorias apontadas e da analogia proposta, surgiu, como mencionado, a possibilidade de mais duas categorias fraseológicas forjadas a partir da prática dessa conjugação entre análise fraseológica e estrutura poética desse tipo de repertório.

\subsection{Verso branco como possível categoria fraseológica}

Propus, como apontado, pensar as estruturas citadas (binárias - período e sentença/ternárias) como possibilidades de quadras e tercetos musicais, respectivamente. Com base na analogia proposta e no sentido de ampliar as possibilidades estruturais, 
pode-se pensar em uma estrutura musical análoga ao verso branco ${ }^{29}$ na qual as frases se mantêm na métrica (quatro frases para período ou sentença e três para estrutura ternária), porém com ausência de repetição fraseológica. Como exemplo dessa possibilidade, apresento a seção A do frevo "Freio a Óleo"30, de 1950, do compositor pernambucano José Menezes. Observa-se que nenhuma frase se repete, apenas o motivo das anacruses dos $2^{\circ}$ e $10^{\circ}$ compassos e, apesar disso, a quadratura está perfeita, com quatro frases em 16 compassos, incluindo a frase cadencial que finaliza a seção. Por outro lado, pode-se considerar a terceira frase c como uma variação da frase $a\left(a^{\prime}\right)$, o que colocaria tal estrutura dentro do esquema do período.

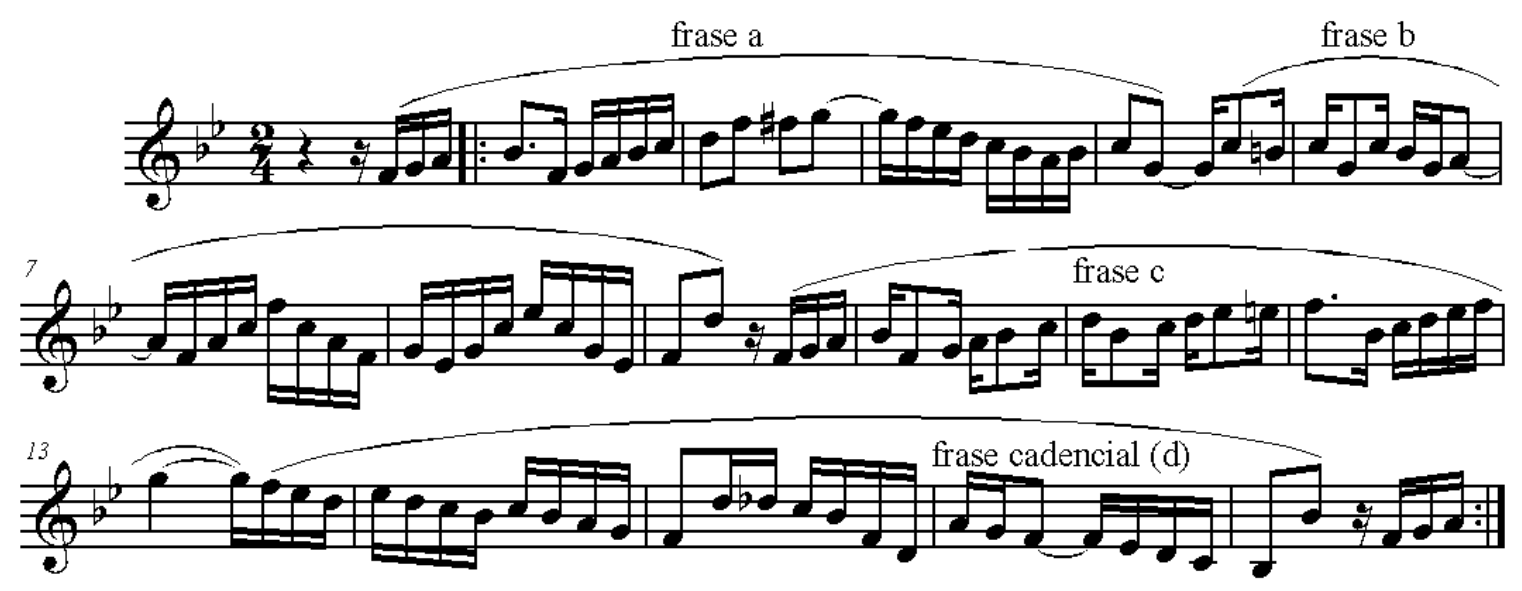

Fig. 8: "Freio a Óleo": seção A

Seria possível dizer, portanto, que a seção A de "Freio a Óleo" é uma estrutura binária em "verso branco". Além disso, por conta das características dos frevos-de-rua ${ }^{31}$ constituídos por duas seções na mesma tonalidade, muitos se encontram em um território fronteiriço entre as formas binárias e ternárias. Claro que, do ponto de vista da execução, o comum é executá-las como formas ternárias (ABA), mas as partituras do gênero e sua característica tonal abrem margem para a possibilidade da forma binária $(A B)$. Isso porque, conforme colocado, tradicionalmente se executa o gênero dentro da forma ternária (ABA), não havendo contraste tonal entre as seções A e B no frevo. Com isso, é perfeitamente possível que o intérprete opte por findar a execução ao término de B. Quando essa seção se encontra em tonalidade de contraste, o retorno é imperativo. Observe o exemplo abaixo:

\footnotetext{
290 verso branco se dá quando a métrica da poesia é mantida, mas não há rima entre os versos.

30 Songbook de Frevos (1998).

31 As três principais categorias básicas do frevo são frevo-de-rua, frevo-canção e frevo-de-bloco. 0 primeiro é instrumental, o segundo e o terceiro são vocais.
} 


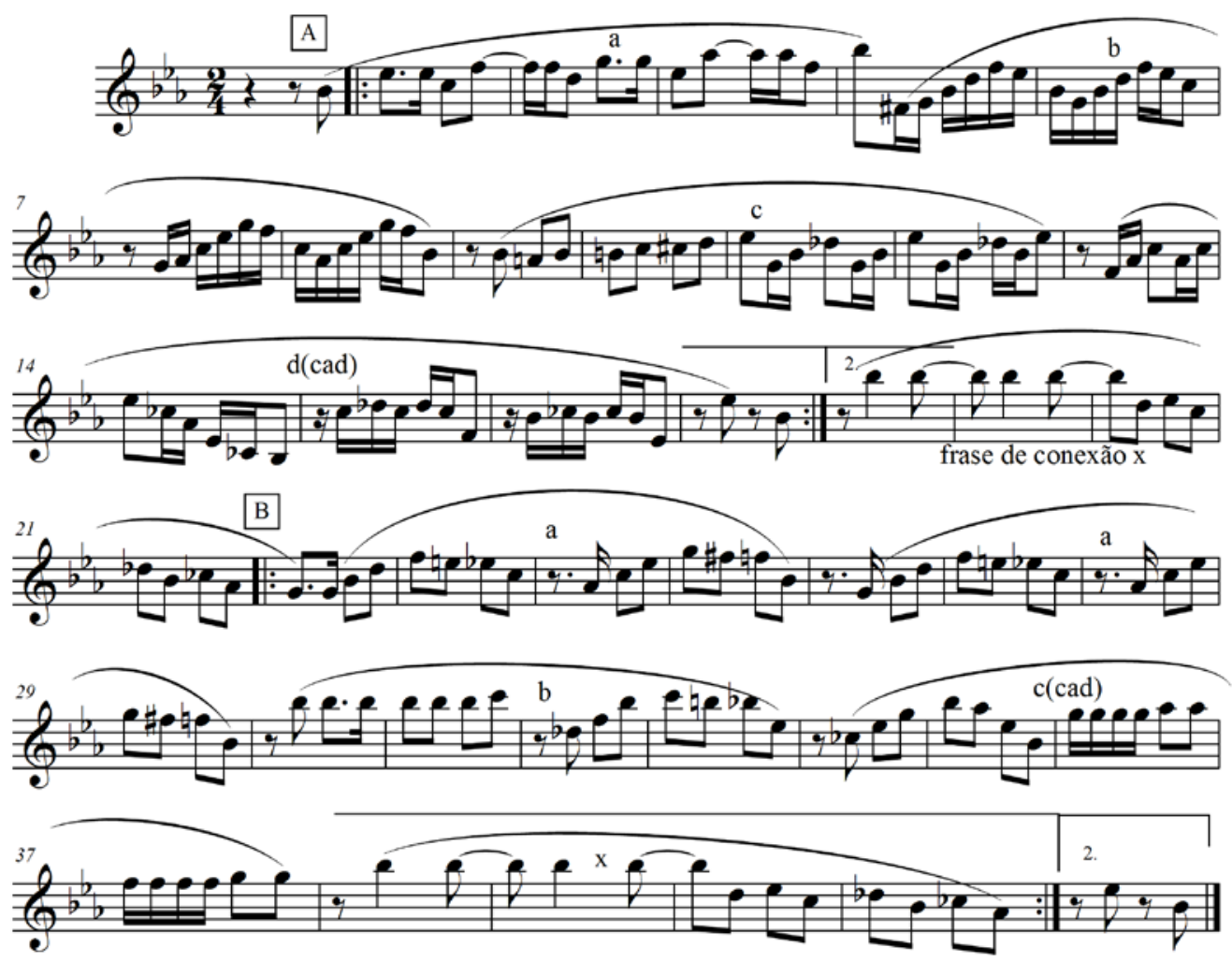

Fig. 9: "Duda no Frevo", de Senô

Trata-se do clássico tema dedicado ao maestro Duda do Recife (José Urcino da Silva) por Senô (Senival Bezerra do Nascimento). Conforme apontado, algumas características fraseológicas parecem constantes do frevo: seções contrastantes na mesma tonalidade; alguma seção estruturada em "verso branco musical" e o uso da frase de conexão. Nesse tema, a seção A e B estão na mesma tonalidade, de Mi bemol maior, trazendo a mencionada característica da facultatividade do retorno à seção A. Essa última é constituída por 16 compassos divididos em antecedente e consequente, perfazendo, assim, uma estrutura binária regular. Como comentado, não há repetição de frases na primeira seção, daí a denominação do "verso branco", no qual não há rima, mas há métrica. A frase de conexão x é uma espécie de frase de soldadura convencionada que liga as seções $A$ e $B$. Ela também realiza o retorno da parte $B$, claramente uma sentença pela repetição literal das frases a, mas é suprimida na segunda vez.

Outros exemplos de temas de frevo com características semelhantes são "Corisco" (Lourival Oliveira), "Gostosinho" e "Gostosão" (Nelson Ferreira), entre outros. Como comentado, talvez esta ausência de repetição fraseológica seja uma característica importante de algumas seções dos frevos-de-rua. Por fim, no caso da estrutura $a, b$ e $c$ (cad.), também se observa o "verso branco", mas em uma estrutura ternária, fato que encontramos, por exemplo, na parte A de "Wave" (Tom Jobim), com 12 compassos, ou A de "Lamentos" (Pixinguinha), com 24 compassos. Essa categoria responderia, parcialmente, na medida em que há mais de uma análise possível, à falta de encaixe mencionada na seção B de "Segura Ele". 


\title{
2.2 Verso livre como categoria possível fraseológica
}

Dentro desse contexto de referência, o compositor e multi-instrumentista alagoano Hermeto Pascoal parece criar uma interessante possibilidade em suas composições, que chamei de "verso livre musical". Diferentemente do verso branco, o verso livre caracteriza-se pela ausência de rima e métrica (GOLDSTEIN, 2005, p.36). No álbum Brasil Universo (1986), o autor realiza na última faixa (Calma de Repente) uma espécie de improvisação verbal através de associações livres de ideias, métricas e rimas preestabelecidas, uma espécie de "repente livre", ainda que, de improviso, muitas rimas e repetições métricas terminem por acontecer, mas de forma assistemática.

\author{
Vou tomar uma massagem \\ Na alma e no coração \\ [...] bem fundo da paixão \\ A afinidade iluminada sentida com emoção \\ Energia renovada nos dedos dos pés e das mãos \\ Ninguém sofre por amor \\ Porque o amor existe \\ Sem parar pelos universos dos céus \\ As estrelas cósmicas e a magia do ar \\ Formosa flor espelhando \\ $A$ verdadeira imagem do amor \\ Vibrando no seu corpo fluidos no coração \\ Raios quentes como o sol \\ Espalham-se nas suas mãos \\ A alma doce meiga e calma \\ Calma, calma, calma. ${ }^{32}$
}

Tal procedimento, acredito, é o que o autor parece transpor para o nível musical puro, por exemplo, na obra "São Paulo, 9 de Julho", uma das 366 músicas de seu Calendário do Som (PASCOAL, 2000). Além da análise fraseológica, a Fig. 10 apresenta a harmonia "transliterada" na pauta. 

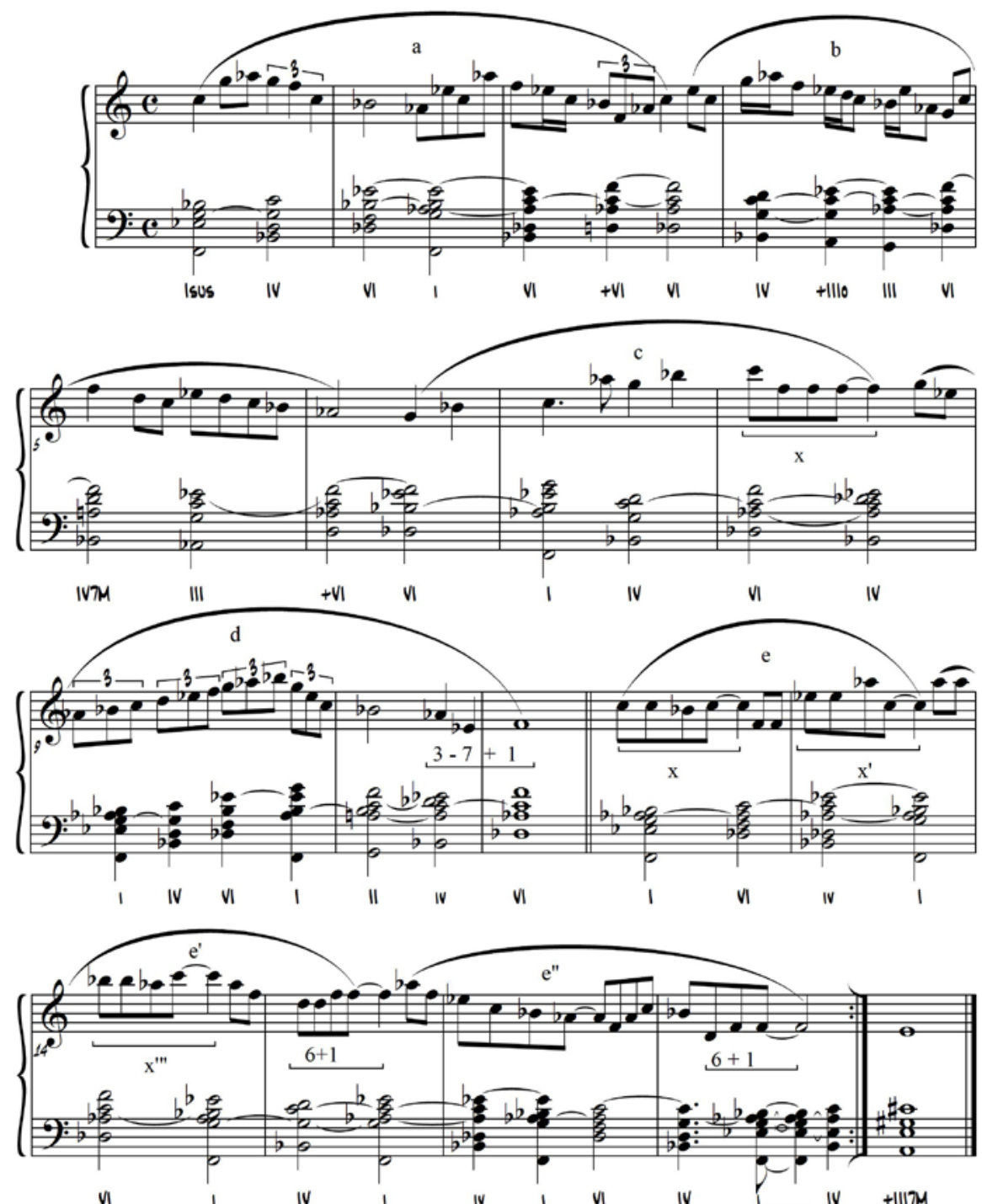

Fig. 10: "São Paulo, 9 de Julho", de Hermeto Pascoal

Nota-se que, até o final da frase $d$ no $11^{\circ}$ compasso, não há nenhuma repetição fraseológica. É somente a partir do 12 - compasso, com a sequência de três frases e e derivadas, que há uma pequena estrutura ternária regular ocupando 6 compassos. É essa ausência de repetição fraseológica que caracterizaria o verso livre musical dos 11 primeiros compassos. Apenas o motivo $x$ e suas derivações fazem uma conexão entre esses mesmos compassos e os seis últimos (do $12^{\circ}$ ao 17으. Nota-se também que toda melodia está baseada num único modo de Fá dórico, muito embora o compositor o harmonize com o uso recorrente de alguns graus, sobretudo I, IV e VI, como indica a análise, mas alterando suas tipologias nesses acordes tomando como base seu provável campo harmônico diatônico de origem (como sus, 7M, 6/9, m7 etc.). Em síntese, o autor realiza uma composição coerente sem lançar mão de repetições fraseológicas até o 11을 compasso e sem abdicar ao uso de um modo diatônico. Além disso, explora as possibilidades idiomáticas ligadas às tradições populares/jazzísticas de harmonização, bem 
como o uso de um dos traços melódicos nordestinos modalizadores característicos: o 6+1 (mas também o 3-7+1), presente em diversos exemplos de música nordestina dentro do escopo abordado, uma das características da "tópica da nordestina", na definição de Piedade (2011). Outras composições de Hermeto parecem atuar na mesma direção de organização fraseológica e processo de harmonização, como "Ilha das Gaivotas ${ }^{33 "}$ e "Mestre Radamés ${ }^{34 ", ~ p o r ~ e x e m p l o . ~}$

Voltando a Schoenberg, mas agora como compositor, durante o seu período de produção classificado como atonal livre, que precede ao dodecafônico, o compositor buscou elaborar obras que, de um lado, evitavam a repetição e, de outro, o tonalismo e, ainda assim, buscavam a coerência ou inteligibilidade. O dado relevante nesse procedimento de Hermeto, portanto, reside no fato de que a ausência de repetição motívica, fraseológica e seccional não está acompanhada pela ausência de tonalidade/modalidade, ainda que, aparentemente, a inteligibilidade permaneça.

\section{Considerações finais}

A partir dos apontamentos e análises realizados, acredita-se que, somente através de uma busca em campo interdisciplinar, se pode acomodar a proposta aqui sugerida. Portanto, os campos da teoria musical, revistos através da poética e de aspectos filosóficos, apontariam para a maturação dos pontos aqui levantados no sentido de uma busca por algo que reúna música e poesia como elementos estruturantes e estruturados mutuamente, o que pode alterar o entendimento e, portanto, a percepção e cognição da música através da analogia proposta. Tal interdisciplinaridade poderia partir da observação de trabalhos relativamente recentes sobre fenômenos formais, como W. Caplin (2013) e Assumpção (2007), sendo que o último os relaciona não à poética, mas a figuras da retórica clássica. Entretanto, ressalta-se que conceitos como os de ideia e de ideia cadencial (MOREIRA, 2018, p.204-205), entre outros, de Caplin, careceram aqui de maturação. As referências de Julio Bas (2010), Arnold Schoenberg (1991), Hugo Riemann (1950) e Joaquin Zamacois (1985) permanecem e a estas somei as de Leon Stein (1979) e Douglas Mac Green (1964), que, como mencionado, foram trabalhadas dentro de uma dimensão prático-analítica.

Por outro lado, há trabalho recente que compara a evolução fraseológica com a métrica poética: é o de Martin Delgado (2016), que se dá no contexto dos gêneros musicais populares argentinos, ou seja, com a presença da letra ou verso poético, o que reforça, a meu ver, alguns dos pontos defendidos a partir da perspectiva deste artigo.

Notemos que em alguns métodos a frase ou estrofe também pode ser considerada como ORAÇÃO. Isto de modo algum é certo, porque, em relação ao texto, a frase musical coincide com uma oração gramatical (não é regra estrita, já que às vezes a oração coincide com a semifrase). Ademais, essa é uma maneira muito interessante de pensar a frase musical em comparação com uma oração que 
expressa uma ideia fechada que se delimita com um ponto, como faz normalmente a cadência. (DELGADO, 2016, p.22).

Em complemento, observou-se a importância da harmonia em alguns pontos das categorizações fraseológicas, como já dado pelos tratadistas em relação aos pontos cadenciais e semicadenciais, ao que se soma uma espécie de vagância da harmonia de "9 de Julho", que corrobora a construção da melodia em "verso livre" ou na harmonia modulatória de "Imagem", que sustenta o interesse na sentença baseada na cadeia de frases. Por outro lado, a regularidade harmônica nos casos do "verso branco" contribui para o pensamento de que a estrutura e os padrões métricos se mantêm em detrimento da falta de repetição fraseológica ou motívica.

Portanto, além da possibilidade de analogia proposta entre os elementos constituintes entre motivo e rima, frase e verso, o artigo procurou apontar outras categorias que, embora pertençam à arte poética, não fazem parte do leque de abordagem analítica de obras musicais do ponto de vista da fraseologia, como os versos branco e livre, ainda que, em alguns casos, haja mais de uma possibilidade de "encaixe" em categorias preexistentes. Porém, a essa altura, o que se pretende não é resolver o problema do encaixe, mas, sobretudo, apontar uma possibilidade que se deixa em aberto.

Para além das chamadas "pequenas formas" - ressaltando que o campo da análise é, sobretudo, um campo de origem formalista que, como já apontado no artigo, tem em seus autores o viés estético/ideológico repousado no ideal europeu da obra-prima, da ideia da obra de arte, dos grandes compositores da música "universal" e da forma sonata como o ápice desse pensamento -, há que se pensar que, em seu processo de decantação em territórios híbridos de música popular urbana, quais tipos de desenvolvimento formal despontaram. Por um lado, arranjos ligados ao jazz e às big bands, pelo menos nas primeiras décadas do swing, tendem a manter o chorus ${ }^{35}$ e, assim, se manter mais próximos ao que poderíamos chamar de paradigma do tema e variação, principalmente porque zelam pela manutenção da improvisação dentro da estrutura do arranjo. Por outro lado, em alguns compositores brasileiros, há uma tendência a se fazer colagens de melodias, uma após a outra, sem que, necessariamente, haja retorno a frases, períodos ou sentenças já expostas. Esse processo, que chamei de "rapsódico" em outras publicações (TINÉ, 2018a, 2018b) ${ }^{36}$ - termo que não deixa de ter sua implicação com o formalismo -, corresponderia a esse outro paradigma. Portanto, a pergunta que se faz a partir daqui é: como se desdobram os temas de "Frevo", "Estamos Ai", "Imagem", "Nanã", "Duda no Frevo" e "9 de Julho" em diferentes arranjos e propostas de interpretação? Pergunta que somente os estudos de caso podem responder, a fim de verificar se a ideia dos dois paradigmas se faz pertinente.

\footnotetext{
350 termo swing aqui se refere à era de nome correspondente na história do jazz. Chorus, no jargão jazzista, é a estrutura da canção (normalmente ternária ou como Canção de Uma Só Parte) cuja harmonia se repete durante as improvisações. Os livros de Rayborn Wright (Inside Score) e Fred Sturm (Changes Over Time) são obras que ilustram bem o fato comentado.

36 Tais publicações dizem respeito, exatamente, às análises de Mestre Radamés e Forró, de autoria de Hermeto Pascoal e Egberto Gismonti, respectivamente, onde tais processos são descritos.
} 


\section{Divagações poéticas (coda rapsódica)}

O filósofo fenomenólogo e existencialista alemão Martin Heidegger (1889-1976) deixou algumas interessantes reflexões sobre conceitos bastante caros à nossa investigação, como linguagem, poesia e canção, compilados em $A$ caminho da linhagem (HEIDEGGER, 2003) ${ }^{37}$. Em primeiro lugar, diferencia o pensamento sobre a linguagem da investigação científica dos linguistas.

[...] fazer uma experiência com a linguagem é algo bem distinto de se adquirir conhecimentos sobre a linguagem. Esses conhecimentos nos são proporcionados e promovidos infinitamente pela ciência da linguagem, pela linguística e pela filologia das diferentes línguas e linguagem, pela psicologia e pela filosofia da linguagem [...] Metalinguística é a metafísica da contínua tecnicização de todas as línguas, com vistas a torná-las um mero instrumento de informação capaz de funcionar interplanetariamente, ou seja, globalmente. (HEIDEGGER, 2003, p.122).

Ou seja, como colocado, para o filósofo, uma coisa seria a experiência com a linguagem, outra, os conhecimentos linguísticos estruturados. Para ele, uma característica essencial da poesia é "trazer à linguagem algo que não foi dito" através do aprendizado do poeta na renúncia, que ele entende por re-enunciar, anunciar de novo. Tal re-nuncia se daria através da experiência da nomeação com a linguagem, ou seja, o ato de nomear, de dar novos significados às palavras. "Nesse campo, o pensamento encontra a vizinhança da poesia. Escutamos sobre a experiência poética da palavra" (HEIDEGGER, 2003, p.140). E então, através da entoação, a palavra se torna canção, ou seja, música.

A canção não é entoada posteriormente. É no ato de entoar que ela começa a ser a canção que ela é. O poeta da canção é o cantador. [...] O canto é a festa da chegada dos deuses, a chegada quando tudo se aquieta. O canto não é o contrário da conversa, mas seu vizinho mais próximo, pois também o canto é linguagem. (HEIDEGGER, 2003, p.141).

Se, então, a linguagem da música nasceu por meio da poesia, pode-se dizer que a poesia nasceu música e, assim, através dessa reflexão, pensar nos gêneros de música popular no Brasil, sobretudo do Nordeste. Mario de Andrade, em seu famoso "Ensaio sobre a Música Brasileira", de 1928, já apontava a semelhança entre os "rapsodos" gregos e os repentistas.

[...] é muito possível que nesses nordestinos a gente vá encontrar uma reprodução contemporânea da maneira de cantar dos rapsodos gregos ou do canto cristão primitivo. Com efeito, se dá neles uma união absoluta da música e da palavra falada, de forma a tornar impossível uma fixação rítmico-musical isolada. É a maneira de falar, natural e despreocupada, que determina às vezes em absoluto a sucessão de sons da melodia. (ANDRADE, s.d., p.140).

\footnotetext{
37 Tais reflexões se dão a partir de trechos do poeta simbolista alemão Stefan George (1833-1933). Apesar dos aporias do filósofo partirem de tais trechos, acredita-se que Heidegger as quis gerais para as reflexões levantadas.
} 
Ainda que possa se tratar da intuição do autor, ligando em sua apropriação pontos tão distantes na história e na geografia, pode-se pensar que, em comum, tais manifestações têm, a princípio, a marca da oralidade. Jaa Torrano (1992), em seu estudo e tradução da "Teogonia" de Hesíodo (século VIII a.C.) - o primeiro poema da história grega e, portanto, da história ocidental -, nos traz o sentido dessa "música poética" ou "poesia musical", que precede a escrita e que, por sua estrutura métrica, sustenta a oralidade na memória.

É através da audição deste canto que o homem comum podia romper os restritos limites de suas possibilidades físicas de movimento e visão [...] e entrar em contato e contemplar figuras, fatos e mundos que pelo poder do canto se tornam audíveis, visíveis e presentes. [...] Memória gera e dá luz às Palavras Cantadas, que na língua de Hesíodo se dizem Musas. [...] Esta extrema importância que se confere ao poeta e à poesia repousa em parte no fato de o poeta ser, dentro da perspectiva de uma cultura oral, um cultor da Memória (no sentido religioso e no da eficiência prática), e em parte no imenso poder que os povos ágrafos sentem na força da palavra e a adoção do alfabeto solapou até quase dormir. (TORRANO, 1992, p.16-17).

Além disso, junto com a oralidade que cultiva a memória através das fórmulas poéticas dentro da cultura oral, repousa a possibilidade da improvisação, tão cara. Segundo Haroldo de Campos e Vieira Trajano (1994), alguns helenistas aproximam poemas homéricos a gêneros musicais por vezes pautados pela improvisação. Esta, por sua vez, pode se fundamentar tanto nas métricas dos repentistas quanto em procedimentos mais desprendidos, como o do verso livre, e ser, igualmente, fundamentado por eles, desprovidos de métrica e rima, outro ponto comentado na citação de Mario de Andrade.

Se, por um lado, o campo da fraseologia musical pôde ser visto aqui em par à arte da retórica, através da filosofia pitagórico/tomista ${ }^{38}$ de Mário Ferreira dos Santos - tendo como ponte o citado trabalho de Sérgio Assumpção - e cuja antologia remonta, em última análise, a Aristóteles, é em outra obra do filósofo grego que, conforme vem sendo apontado, o campo pode pousar raízes. Paula Siqueira (2009), ao abordar a obra "Tempo e Narrativa" do filósofo, também associado à fenomenologia mas na linha da hermenêutica, Paul Ricoeur (1913-2005), considera que essa realiza um trabalho de exegese entre os clássicos "Poética" de Aristóteles e "Confissões" de Santo Agostinho, vendo cada obra como sendo o inverso da outra e que, então, a experiência do tempo se dá, através da linguagem (canto, recitação, escrita e fala), em experiências narrativas.

Por esta razão a narrativa revela-se uma das atividades de linguagem que articulam a experiência humana do tempo, constituindo-se uma das condições para que ele aceda ao mundo e à consciência. Essa atividade eminentemente verbal - a narrativa - se mostra apta para "dizer o tempo" ou "enunciá-lo", pois "se desdobra nas várias dobras do tempo", apreendendo-o e configurando-o. (SIQUEIRA, 2007, p.56).

Na música popular, assim como no cinema, a partir do século $X X$, a experiência narrativa do tempo artístico se viu poeticamente "esculpida", para usar a expressão 
do cineasta russo Andrei Tarkovisky, por meios tecnológicos. Assim, assentou-se mais fortemente dentro de uma tradição inventada que o musicólogo Vicenzo Caporaletti (1955) denominou por "audiotácil" a partir da proposta de um novo código "aural", ou seja, de uma tradição não mais ligada parcialmente à matriz visual (ligado à partitura) e, portanto, vinculada somente aos processos de manipulação e reprodução sonora. Voltando à questão inicial do artigo, sobre a repetição de elementos musicais como rima, independentemente do fato de o gênero ser aberto ou não para improvisação, essa se dá, a partir desse ponto, na própria repetição do fonograma. Tais repetições, se feitas à exaustão, findam por familiarizar o ouvinte com a estranheza da não repetição motívica e, assim, trazem previsibilidade à escuta, naturalizando a escuta de músicas como "9 de Julho" e as citadas "Mestre Radamés" e "Ilha das Gaivotas". Portanto, a narrativa do tempo obtida através de muitas repetições de uma determinada performance pode amplificar a vivência da rima, da poesia e da experiência da linguagem.

\section{Referências}

A ARTE da Cantoria: Ciclo do Cangaço. São Paulo: Instituto Itaú Cultural, [s. d.]. 1 CD.

ANDRADE, Mario de. Ensaio sobre a música brasileira. São Paulo: Ed. Livraria Martins, [s.d.].

ASSUMPÇÃO, Sérgio E. M. Ascendência retórica das formas musicais. Dissertação (Mestrado) - ECA, USP, São Paulo, 2007.

BAS, Julio. Tratado de La Forma Musical. Buenos Aires: Melos, 2010.

BRASIL Universo. Compositor: Hermeto Pascoal. São Paulo: Som da Gente, 1985. 1 LP/CD.

CAMPOS, Haroldo; VIEIRA, Trajano. A Ira de Aquiles. Canto I da llíada de Homero. São Paulo: Nova Alexandria, 1994.

CAPLIN, William. Analizing classical form: an approach for the classroom. New York: Oxford University Press, 2013.

COISAS. Compositor: Moacir Santos. Rio de Janeiro: Forma, 1965. 1 LP/CD.

CHEDIAK, Almir (org.). Songbook da Bossa Nova. 2. ed. Org. Almir Chediak. Rio de Janeiro: Lumiar, 1990. v. 1.1 partitura.

DUNSBY, Jonathan; WHITTAL, Arnold. Análise musical na teoria e na prática. Trad. Norton Dudeque. Curitiba: Ed. UFPR, 2011.

GREEN, Douglass M. Form in Tonal Music: an introduction to analysis. New York: Holt Rinehart and Wiston Inc., 1964. 
GOLDSTEIN, Norma. Versos, sons, ritmos. 13. ed. São Paulo: Ática, 13. ed., 2005.

HEIDEGGER, Martin. A caminho da linguagem. Trad. Márcia Sá Cavalcanti Shuback. Petrópolis: Vozes, 2003.

HESÍODO. Teogonia: a origem dos deuses. Estudos e Tradução Jaa Torrano. São Paulo: Iluminuras, 1992.

LACERDA, Marcos Branda. Música de culto nagô-iorubá e a Barform. In: ENCONTRO NACIONAL DA ANPPOM, 13., 2001, Belo Horizonte. Anais [...]. Belo Horizonte, 2001. V. 1, p. 308-315.

LAGOA da Canoa do Município de Arapiraca. Compositor: Hermeto Pascoal. São Paulo: Som da Gente, 1984. 1 LP/CD.

MELLO, Marcelo. Reflexões sobre linguística e cognição musical. Dissertação (Mestrado) - Unicamp, Campinas, 2003.

MOREIRA, Gabriel; NAVIA, Gabriel. Período, sentença ou híbridos? Aplicações da teoria das funções formais no estudo da forma do choro. Musica Theorica: Revista da Associação Brasileira de Teoria e Análise Musical, v. 4, n. 2, p. 159-181, 2019.

MOREIRA, Sílvio. O semisimbolismo nas permutas de A Permuta dos Santos. In: GEPOEX (org.).; VICENTE, Antonio (coord.). Ensaios de arte experimental. São Paulo: Córrego, 2018.

OLIVEIRA, Willy Correa. [Entrevista concedida à] Revista Concerto, ano XI, n. 115, mar. 2006.

PASCOAL, Hermeto. Calendário do Som. São Paulo: Ed. Senac Instituto Cultural Itaú, 2000. 1 partitura.

PIEDADE, Acácio. Perseguindo os fios da meada: pensamentos sobre hibridismos, musicalidades e tópicas. Per Musi, Belo Horizonte, n. 23, p. 103-112, 2011.

RAMALHO, Elba Braga. Cantoria nordestina: música e palavra. São Paulo: Terceira Margem, 2000.

RIEMANN, Hugo. Composición Musical (Teoria de la Formas Musicales). Trad. Roberto Gerhard. Barcelona: Labor, 1950.

SANTOS, Mário Ferreira. Curso de oratória e retórica. 3. ed. São Paulo: Logos, 1954. 
SANTOS, Mário Ferreira. Dicionário de filosofia e ciências culturais. São Paulo: Matese, 1963.

SANTOS, Mário Ferreira. Pitágoras e o Tema do Número. São Paulo: Ibrasa, 2000.

SCHOENBERG, Arnold. Fundamentos da composição musical. Trad. Eduardo

Seincman. São Paulo: Ed. USP, 1991.

SANTOS, Mário Ferreira. Funções estruturais da harmonia. Trad. Eduardo Seincman. São Paulo: Via Lettere, 2004.

SIQUEIRA, Paula. A hermenêutica de Paul Ricoeur: da poética à teoria da narrativa e à identidade narrativa. Tese (Doutorado) - Faculdade de Educação, USP, São Paulo, 2009.

SÓ Não Toca Quem Não Quer. Compositor: Hermeto Pascoal. São Paulo: Som da Gente, 1989. 1 LP/CD.

SONGBOOK de Frevos. Recife: Prefeitura da Cidade do Recife, 2003. 1 partitura.

STEIN, Leon. Structure and style. Miami: Summy-Birchard, 1979.

TINÉ, Paulo. Compositores da Música Popular do Brasil: Pixinguinha, Garoto e Tom Jobim. Uma análise comparativa que abrange o período do Choro a Bossa Nova. Dissertação (Mestrado) - ECA, USP, São Paulo, 2001.

TINÉ, Paulo. Procedimentos Modais da Música Popular do Brasil: do campo étnico do Nordeste ao popular da década de 1960. Tese (Doutorado) - ECA, USP, São Paulo, 2008.

TINÉ, Paulo. A Metáfora da Coisa: inflexões heideggerianas na canção de Gilberto Gil. In: TOMÁS, Lia (org.). Fronteiras da Música: Filosofia, Estética, História e Política. Série Pesquisa em Música no Brasil, Vol. 6. São Paulo: Anppom, 2016. v. 6 (Série Pesquisa em Música no Brasil)

TINÉ, Paulo. Meditações acerca da canção "Sobre Todas as Coisas" de Edu Lobo \& Chico Buarque. In: SEFIM, 2017, Porto Alegre. Anais [...]. Porto Alegre, v. 3, n. 4, 2017. p. 75-84.

TINÉ, Paulo. As escolhas estético-musicais de Egberto Gismonti a partir da peça "Forró": brasilidade, vanguarda e sacralidade". In: FMCB, 5., 2018, Campinas. Anais [...]. Campinas: FMCB, 2018a. p. 32-47. 
TINÉ, Paulo. O Tempo de Hermeto Pascoal: simultaneidade de acontecimentos em 'Mestre Radamés' e seu contexto. Per Musi, Belo Horizonte: UFMG, p. 1-16, 2018b.

TINÉ, Paulo. Um Arranjo pra Nanã de Moacir Santos e outras coisas: da possibilidade de contribuição da análise musical em sua elaboração final. In: CONGRESSO DA ANPPOM, 29., 2019, Pelotas. Anais [...]. Pelotas, 2019.

TINÉ, Paulo. Harmonia: fundamentos de arranjo e improvisação. 3. ed. São Paulo: Rondó, 2020.

VOCÊ ainda não ouviu nada. Intérpretes: Sérgio Mendes; Bossa Rio. [S. l.]: Você Ainda Não Ouviu Nada. Universal, 2002. 1 LP/CD.

ZAMACOIS, J. Curso de formas musicales. Barcelona: Labor, 1985.

WEBERN, Anton. O caminho para a música nova. Trad. Carlos Kater. São Paulo: Novas Metas, 1984. 